\title{
POŠTA
}

TELEKOMUNIKÁCIE A

ELEKTRONICKY OBCHOD

\section{KONKURENCIESCHOPNOSŤ PODNIKOV V PODMIENKACH EURÓPSKEJ INTEGRÁCIE A GLOBALIZÁCIE}

\author{
Katarína Štofková*
}

Úvod

$\mathrm{V}$ súčasnom dynamickom a náročnom podnikatel'skom prostredí sa konkurencieschopnost' stala hlavným motívom rozvojových stratégií štátov a regiónov. Z Lisabonského summitu EÚ vyplýva, že ciel’om členských krajín je vybudovat' na európskom kontinente najkonkurencieschopnejšiu ekonomiku sveta založenú na znalostiach. Rastúca dynamika zmien v podnikatel'skom prostredí má novú kvalitu, pričom niektorí ekonómovia sú toho názoru, že prosperita podnikov sa vytvára z chaosu a spoločnost' je označovaná ako vedomostná. Pre podniky je požiadavka odhalenia mechanizmu, ktorá im dala dostatočnú nádej nielen na prežitie v týchto podmienkach ale aj možnost' rozvíjat' sa a predovšetkým byt' konkurencieschopným. V otázkach konkurencieschopnosti podnikov sa zdôrazňuje celý rad faktorov - lacná pracovná sila, kvalifikácia, prispôsobivost' podmienkam, dostupnost' surovín, lepšie technológie, vyššia produktivita práce, lepšie podmienky na trhu a pod. Uvedené klasické faktory v kombinácii s tzv. mäkkými faktormi , ako sú identita, integrita, suverenita a mobility v konkurenčnej sút’aži obstoja lepšie. Jedným z prístupov, ktorý môže pomôct' riešit' problematiku konkurencieschopnosti je aj oblast' skúmania sietí a klustrov a možnost' ich aplikácie do praxe. Rozhodujúcim nástrojom pre rast inovačnej kapacity, produktivity a regionálnej konkurencieschopnosti sú podl'a súčasného svetového prístupu vzájomne a geograficky previazané zoskupenia firiem v rámci blízkeho odvetvia, tzv. klustre.

\section{Vytváranie sietí malých a stredných podnikov}

Siet' podnikov (Business Network) definuje OECD ako skupinu podnikov, ktoré používajú rovnaké zdroje ku kooperácii na spoločných projekoch. Podl'a väčšiny autorov je podnikatel'ská siet' charakterizovaná ako skupina dvoch alebo viacerých podnikov, ktoré spolupracujú, aby realizovali nové podnikatel'ské aktivity, ktoré by samostatne bolo nemožné realizovat' [3]. Ide o formu podnikania, realizovanú na kooperačných vzt'ahoch medzi podnikatel'skými a inými subjektami. Siet' zvyšuje rýchlost' pohybu informácií a má vplyv na finančné efekty podnikania, pričom premieňa klasický podnik na virtuálnu korporáciu, ktorá obsahuje „technologické jadro“ a ostatné činnosti prebiehajú vo vytvorenej sieti podnikatel'ských subjektov. Spoločnými charakteristikami sietí sú [6]:

- pomerne malý počet zahrnutých podnikov,

- obmedzené členstvo, ktoré má často podobu skôr horizontálnych vzt’ahov medzi podnikmi porovnatel'nej vel'kosti, ako typickú hierarchickú štruktúru dodávatel'ského ret'azca napojeného na väčší podnik,

\footnotetext{
* Ing. Katarína Štofková, PhD. Žilinská univerzita v Žiline, Fakulta prevádzky a ekonomiky dopravy a spojov, Katedra spojov, Univerzitná 1, 01026 Žilina, tel. 041 5133136, e-mail: katarina.stofkova@fpedas.uniza.sk
} 
- spoliehanie sa na vývoj silných väzieb odvodených z dôvery, povesti alebo reciprocity,

- nemusí vždy íst' o právny kontrakt, ale vždy je určitý druh dohody, napr. slovný, pre vykonanie dohodnutých akcií, záväzok k poskytnutiu určitých zdrojov a podobne.

Siete vznikajú medzi vel'kými podnikmi a ich subdodávatel'mi, medzi malými a strednými podnikmi, medzi podnikatel'skými subjektmi a verejným sektorom, občianskou verejnost'ou a pod. Vel'ké podniky realizujú rozsiahle (globálne) siete, avšak aj vel'mi malé podniky môžu mat' globálny charakter a generovat' zisky, ak využijú vhodné formy globálnej siete [2].

Vzájomné prepájanie a väzby medzi jednotlivými podnikatel’skými subjektmi, tzv. pretkávanie vzt'ahov, vedie k vzniku siete. Ciel'om prepájania podnikov je predovšetkým zvýšenie konkurenčnej schopnosti, a to prostredníctvom [3]:

- znižovania nákladov pri uzatváraní transakcií,

- znižovania výrobných nákladov,

- rozširovania prístupu k moderným technológiám, informáciám,

- spoločným vytváraním nových informačných databáz,

- rýchlejším zavádzaním noviniek,

- získavaním možností vstupovat' na nové trhy a

- rozdel'ovaním rizika medzi jednotlivé subjekty siete.

K vytváraniu sietí a prepájaniu samotných malých a stredných podnikov nejestvuje jednotný návod. Potreba musí vychádzat' od samých podnikatel'ských subjektov, ktorí sa presvedčia o tom, že zapojením sa do siete získajú výhody, ktoré by boli ináč pre ne nedostupné [4].

V procese prepájania a vytvárania sietí malých a stredných podnikov štát a samosprávne orgány môžu zohrávat’ významnú úlohu, ktorá spočíva v podpore týchto snáh a v mobilizovaní síl podnikatel'skej sféry. Podpora procesov prepájania aktívnych a flexibilných malých a stredných podnikov v regióne, podporí zároveň tvorbu nových pracovných miest, zvýši konkurenčnú schopnost' nielen samotných podnikatel'ských subjektov, ale aj regiónu. V podmienkach globalizácie ekonomických procesov si už vel’akrát nekonkurujú podniky, ale štáty či regióny, ktoré získavajú „punc“ subjektov podnikania.

\section{Prístupy k rozvoju klastrov}

Pojem klaster siaha d’alej ako sú známe „siete podnikov“, v ktorých spolupracujú firmy, ktoré pôsobia na rovnakom trhu koncových produktov a ktoré patria do rovnakej skupiny v rámci odvetvia. Klastre sú často medzisektorové siete (vertikálne alebo laterálne) a zahŕňajú odlišné a komplementárne firmy špecializované okolo špecifických väzieb, alebo na základe vedomostí $\mathrm{v}$ rámci hodnotového ret’azca. Klastre podporujú vznik základných podmienok pre vytváranie inovácií, pričom stimulujú rast sofistikovanej pracovnej sily, rozvoj znalostí a technologií v určitom odbore. Výsledkom ich vývoja je tendencia exportovat' nielen výrobky a služby, ale tiež intelektuálny kapitál a technológie. Klastre ako systémy previazaných firiem a inštitúcií predstavujú nový, komplementárny spôsob chápania ekonomiky. Jedna z príčin nízkej produktivity a konkurencieschopnosti sú nízke investície do inovácií. Avšak zatial čo požiadavka na rast inovácií a produktivity vyžaduje stabilnú makroekonomickú politiku, skutočná hybná sila vychádza z mikroekonomickej úrovne a špeciálne z tzv. klastrov. Inovácie nezahrňujú len výdavky do vedy a výskumu, ale sú silne ovplyvnené prítomnostou klastrov (Skokan, 2004). Porovnanie základných znakov sietí a klastrov je uvedené v tabul'ke č.1. Siete, najmä medzi firmami vo výrobnom ret'azci, sú základnými zložkami každého klastra. 
Tab. č. 1 Základné znaky sietí a clustrov (zdroj: Rosenfeld, 2001)

\begin{tabular}{|c|c|}
\hline Clustre & Siete podnikov \\
\hline $\begin{array}{l}\text { 1. Prit'ahujú požadované špecializované } \\
\text { služby do regiónu }\end{array}$ & $\begin{array}{l}\text { 2. Umožňujú podnikom prístup ku } \\
\text { špecializovaným službám }\end{array}$ \\
\hline 2. Majú otvorené členstvo & 3. Majú obmedzené členstvo \\
\hline $\begin{array}{l}\text { 3. Sú postavené na spoločných hodnotách, } \\
\text { ktoré posilňujú dôveru a povzbudzujú } \\
\text { reciprocitu }\end{array}$ & $\begin{array}{l}\text { 4. Založené sú často na } \\
\text { zmluvných dohodách }\end{array}$ \\
\hline $\begin{array}{l}\text { 4. Generujú dopyt pre viac podnikov s } \\
\text { podobnými alebo príbuznými } \\
\text { schopnost’ami }\end{array}$ & $\begin{array}{l}\text { 5. Ul'ahčujú podnikom podiel'at' sa na } \\
\text { zložitých výrobách }\end{array}$ \\
\hline $\begin{array}{l}\text { 5. Sú založené na kooperácii i na } \\
\text { konkurencii (sút’ažení) }\end{array}$ & 6. Sú založené na kooperácii \\
\hline 6. Majú spoločné vízie & 7. Majú spoločné podnikatel'ské ciele \\
\hline
\end{tabular}

Kluster je charakterizovaný ako „geografické sústredenie vzájomne previazaných odvetví (podnikov), špecializovaných dodávatel'ov, poskytovatel'ov služieb, firiem v príbuzných odvetviach a pridružených inštitúciách, ako sú univerzity, agentúry a obchodné asociácie rôznych smerov, ktoré sút’ažia, ale aj spolupracujúc“. [5].

Základné faktory, ktoré podporujú zhlukovanie odvetví do klustrov, vyplývajú z aglomeračných úspor. Firmy umiestnené $\mathrm{v}$ priestorovej blízkosti profitujú $\mathrm{Z}$ nižších dopravných a transakčných nákladov a z kvalifikovanej a vzdelanej pracovnej sily v danom odvetví. Aglomeračné úspory môžu zasa povzbudzovat' konkurenciu, čo znamená prenos informácií, vedomostí a transfer technológií medzi podnikmi. Môže to viest' k novému rastu odvetví a teda k celkovému rastu klastra.

K rozvoju klastrov prispievajú aj aglomeračné efekty. Tzv. „klastrovanie odvetví a firiem“ je založené na externých výhodách $\mathrm{z}$ aglomerácie a na spoločných akciách fïriem sústredených $\mathrm{v}$ danom priestore, ktoré im spoločne prinášajú úspory, podporujú ich $\mathrm{k}$ zavádzaniu inovácií, k súpereniu a ku konkurencieschopnosti. Hlavné výhody klastrov pre zvýšenie regionálnej konkurencieschopnosti sa prejavujú v nasledovných oblastiach [6]:

Klastre zvyšujú produktivitu a efektívnost', čo znamená:

- efektívny prístup ku špecializovaným vstupom, zamestnancom, informáciám, inštitúciám a verejným statkom, ako sú vzdelávacie programy a vzdelávacie inštitúcie,

- ul'ahčenie koordinácie medzi firmami,

- rýchle rozširovanie najlepších skúseností,

- trvalé a viditel'né porovnávanie výkonnosti a silná motivácia zlepšovat' sa v porovnaní s miestnymi konkurentmi.

Klastre stimulujú a ulahčujú implementáciu inovácií:

$>$ lepšia schopnost' vnímat' inovačné príležitosti,

$>$ prítomnost' dodávatel'ov a inštitúcií, ktoré pomáhajú získavat' vedomosti,

$>$ jednoduché experimentovanie s lokálne prítomnými zdrojmi.

Klastre ul'ahčujú komercionalizáciu:

- zvýšenie príležitostí pre nové podniky a vznik nových podnikov,

- nižšie bariéry vstupu do klastra pre príbuzné podniky z dôvodu dostupných pracovných síl, kvalifikácie, dodávok,

- zvýšenie konkurencie prostredníctvom externalít, väzieb a vzt'ahov medzi firmami a inštitúciami.

Klastre vedú k zvýšeniu ekonomického rastu hlavne z dôvodov: 
$>$ zvyšujú produktivitu tým, že umožňujú prístup $\mathrm{k}$ špecializovaným vstupom a zamestnancom, zvyšujú možnosti prístupu k informáciám, k inštitúciám a pod.,

$>$ zvyšujú inovačnú kapacitu firiem zrýchl'ovaním difúzie technologických znalostí a inovácií; konkurenčné tlaky vnútri klastra zvyšujú samotné ponuky k inováciám,

$>$ stimulujú rýchlejšiu tvorbu nových firiem, pretože mnohí zamestnanci sa stávajú podnikatel'mi v tzv. spin-off firmách, ktoré vznikajú odštiepením od pôvodnej firmy v dôsledku nižších bariér vstupu.

Na rozvoji klastrov a tým aj regionálnej produktivity a konkurencieschopnosti sa podiel'a aj verejný sektor, spolupracujúce inštitúcie, súkromný sektor. Klastre prosperujú tam, kde existuje vysoko kvalitné mikroekonomické podnikatel'ské prostredie. Ich súčast'ou sú poskytovatelia špecializovaných služieb, ako napr. reklama a public relations, ale aj univerzity, výskumné ústavy apod. Pre firmy je totiž jednoduchšie vnímat' príležitosti, rozvíjat' a zavádzat' nové myšlienky, ak sú umiestnené uprostred podobných firiem a v blízkosti dodávatel'ov. Dochádza ku zvyšovaniu konkurenčnej výhody podnikov v klastri prostredníctvom externalít a väzieb medzi firmami, odvetviami v rámci klastra.

\section{Záver}

Problematika konkurencieschopnosti malých a stredných podnikov je vysoko aktuálna predovšetkým v súčasnej dobe globalizácie, kedy nie je jednoduché obstát' na národných trhoch. V nových podmienkach konkurenčnej ekonomiky prežijú malé a stredné podniky nie jednotlivo, ale pomocou spájania sa a vytvárania väzieb s inými podnikatel'skými subjektami a zároveň tak, že budú žit' v symbióze $\mathrm{s}$ daným regiónom a d’alšími subjektami, ktoré v ňom existujú. Zhlukovanie do klastrov je dynamický proces a súvisí úzko s konkurenciou, ktorá zasa závisí na inováciách a vyhl’adávaní strategických rozdielov medzi firmami.

\section{Literatúra}

[1] ČOREJOVÁ, T.: K hodnoteniu regionálneho podnikatel'ského prostredia. Rozwoj Euroregionu Beskidy 2, Bielsko Biala, WSBiF, 2003

[2] LUDVÍK, L.: Podmínky pro sítě malého a středního podnikání. Podnik a podnikání, sborník př́spěvků. Ostrava: Ekonomická fakulta VŠB - TU Ostrava 2002

[3] MARKOVÁ, V.: Malé a stredné podnikanie v Slovenskej republike. Banská Bystrica: Ekonomická fakulta, UMB v Banskej Bystrici, 2003

[4] MIKOLÁŠ, Z.: Small and medium - size enterprise. Katowice: Akademia ekonomiczna, 2002

[5] PORTER, M.: Measuring the Role of Clusters. The Economic Performance of Regions, Gothenburg 2003

[6] SKOKAN, K.: Konkurenceschopnost, inovace a klastry v regionálním rozvoji. Ostrava: Repronis, 2004

[7] ŠTOFKOVÁ, K. in : ŠTOFKOVÁ, J.: Manažment podniku. Žilinská univerzita v Žiline, 2011

[8] SKOKAN, K.: Konkurenceschopnost, inovace a klastry v regionálním rozvoji, Repronis, Ostrava 2004

[9] Rosenfeld, S. A.: Backing into clusters: Retrofitting Public Policies. In Integration Pressures: Lessons from Around the World. J.F. Kennedy School Symposium, Harvard University, March 29-30,2001.

\section{Grantová podpora}

Príspevok je publikovaný v rámci riešenia projektov VEGA 1/1321/12, VEGA 1/0895/13, KEGA 070/ZU-4/2011. 